\title{
OPTIMASI KOMBINASI ASAM SITRAT DAN ASAM TARTRAT SEBAGAI ZAT PENGASAM PADA TABLET EFFERVESCENT EKSTRAK UBI JALAR UNGU (Ipomoea batatas L)
}

\section{Optimization of the Combination of Citric Acid and Tartaric Acid as an Acidifying Agent in Effervescent Tablets of Purple Sweet Potato Extract (Ipomoea batatas L)}

\author{
Dahlia Syahrina ${ }^{\text {* }}$ \\ Noval ${ }^{\prime}$ \\ *I Pharmacy Department, \\ Health Faculty, Sari Mulia \\ University, Banjarmasin City, \\ South Borneo 70238, Indonesia \\ *email: \\ dahliasyahrinal4@gmail.com
}

\section{Kata Kunci:}

Ubi jalar ungu (Ipomoea batatas L)

Asam sitrat dan asam tartrat Tablet effervescent

\section{Keywords:}

Purple sweet potato (Ipomoea batatas L)

Citric acid and tartaric acid Effervescent tablets

\begin{abstract}
Abstrak
Ubi jalar ungu memiliki kandungan senyawa antosianin yang berkhasiat sebagai antioksidan, untuk menghantarkan senyawa berkhasiat tersebut diperlukan formulasi sediaan tablet effervescent sebagai antioksidan dengan kombinasi asam sitrat dan asam tartrat guna mempercepat kelarutan obat. Penelitian bertujuan untuk melakukan optimasi kombinasi asam sitrat dan asam tartrat sebagai zat pengasam pada tablet effervescent ekstrak ubi jalar ungu dengan menggunakan metode simplex lattice design. Pembuatan tablet menggunakan metode kempa langsung dengan evaluasi serbuk effervescent meliputi uji laju alir, sudut diam, kompresibilitas dan kelembaban serbuk. Evaluasi tablet meliputi uji organoleptik, keseragaman bobot tablet, kekerasan, kerapuhan dan waktu larut tablet. Analisis data dengan menggunakan metode simplex lattice design software design expert versi 10.0. Hasil evaluasi serbuk effervescent meliputi uji laju alir, sudut diam, kompresibilitas dan kelembaban serbuk pada setiap formula sudah memenuhi persyaratan. Hasil evaluasi fisik pada uji keseragaman bobot tablet effervescent pada F3, F4 dan F5 sudah memenuhi persyaratan, serta pada evaluasi kekerasan tablet yaitu FI dan F2 juga memenuhi persyaratan. Adapun hasil evaluasi kerapuhan dan waktu larut tablet sudah memenuhi persyaratan pada semua formula. Hasil analisis simplex lattice design didapatkan F5 sebagai formula yang paling optimal dengan konsentrasi asam sitrat 103,25 mg dan asam tartrat 44,25 mg. Kombinasi asam sitrat dan asam tartrat berpengaruh terhadap evaluasi kekerasan, kerapuhan dan waktu larut tablet effervescent ekstrak ubi jalar ungu. Konsentrasi optimal berdasarkan analisis simplex lattice design didapatkan pada F5 dengan konsentrasi asam sitrat 103,25 mg dan asam tartrat $44,25 \mathrm{mg}$.
\end{abstract}

\begin{abstract}
Purple sweet potato has the content of anthocyanin compounds that are efficacious as antioxidants, to deliver these efficacious compounds are required formulations of effervescent tablets as antioxidants with a combination of citric acid and tartrate acid to accelerate the solubility of the drug. Research aims to carry out optimization of the combination of citric acid and tartrate acid as a sourgent on effervescent tablets of purple sweet potato extract using simplex lattice design method. The manufacture of tablets using direct pumping method with effervescent powder evaluation includes flow rate test, silent angle, compressibility and moisture of powder. Evaluation of tablets includes organoleptic tests, uniformity of tablet weight, hardness, fragility and soluble time of tablets. Data analysis using simplex lattice design software design expert version 10. The results of effervescent powder evaluation include test of flow rate, quiet angle, compressibility and moisture of powder in each formula already meets the requirements. The results of physical evaluation on the effervescent tablet weight uniformity test on F3, F4 and F5 have met the requirements, as well as on the evaluation of tablet hardness $\mathrm{FI}$ and $\mathrm{F} 2$ also meet the requirements. The results of the evaluation of fragility and time dissolve tablets have met the requirements on all formulas. The results of simplex lattice design analysis obtained F5 as the most optimal formula with a concentration of citric acid $103.25 \mathrm{mg}$ and tartrate acid $44.25 \mathrm{mg}$. The combination of citric acid and tartic acid affects the evaluation of hardness, fragility and time-soluble effervescent tablets of purple sweet potato extract. The optimal concentration based on simplex lattice design analysis was obtained in F5 with a citric acid concentration of $103.25 \mathrm{mg}$ and tartrate acid of $44.25 \mathrm{mg}$.
\end{abstract}




\section{PENDAHULUAN}

Antioksidan merupakan senyawa yang dapat menangkal dan menstabilkan kerusakan sel akibat radikal bebas (Runtuwene \& Wewengkang, 2016). Flavonoid merupakan salah satu antioksidan alami dengan zat warna Antosianin yang dapat mencegah kerusakan sel karena radikal bebas (Hamid et al., 2010). Antosianin yang berkhasiat sebagai antioksidan mempunyai peranan dalam menstabilkan dan mencegah radikal bebas serta mencegah berbagai penyakit degeneratif seperti penyakit kardiovaskular, aterosklerosis dan antihiperglikemik serta mempunyai peranan untuk meningkatkan sistem imun tubuh (Forbes-Hernandez et al., 2017) (Wahyuningsih et al., 2017).

Dampak dari radikal bebas bisa dicegah dengan menerapkan pola hidup sehat, olahraga teratur serta mengkonsumsi suplemen makanan yang kaya akan kandungan antioksidan. Namun, pemanfaatan formulasi sediaan obat sintetis masih banyak digunakan oleh masyarakat, sehingga perlu adanya pengembangan dan pemanfataan tanaman berkhasiat obat yang bisa digunakan untuk menangkal radikal bebas (Noval et al., 202I). Ubi jalar ungu (Ipomoea batatas L.) merupakan tanaman yang sering dimanfaatkan masyarakat sebagai makanan olahan yang kaya akan antioksidan.

Dosis antosianin yang memiliki efektivitas untuk menjaga kesehatan dan mencegah penyakit kronis pada wanita berkisar 19,8 mg - 94,9 mg, sedangkan pada laki-laki berkisar antara $18,4 \mathrm{mg}-44,1 \mathrm{mg}$ setiap hari (Priska $M$ et al., 2018). Menurut penelitian Safari $A$ et al (2019) yang membandingkan intensitas antioksidan ubi jalar ungu dengan asam askorbat menyebutkan bahwa ekstrak ubi jalar ungu memiliki nilai $I_{50}$ sebesar $4 \mathrm{I}, \mathrm{I} \pm$ 7,3 ppm, ekstrak ubi jalar ungu dan asam askorbat tergolong antioksidan yang sangat kuat untuk menangkal radikal bebas sesuai dengan penggolongan yang dikelompokkan oleh (Tristantini et al., 2016). Kandungan senyawa antosianin sebagai sumber antioksidan alami dari ubi jalar ungu perlu dibuat suatu sediaan obat karena banyaknya manfaat dari kandungan senyawa tersebut, sehingga diperlukan suatu formulasi sediaan yang dapat menghantarkan senyawa berkhasiat dari tanaman ubi jalar ungu (Noval et al., 2019). Tablet effervescent menjadi pilihan untuk pengembangan sediaan dari ekstrak ubi jalar ungu.

Tablet effervescent merupakan sediaan yang nyaman dan mudah untuk pemberian zat aktif obat, terlarut dalam air dan diminum secara oral dalam bentuk larutan sehingga dapat meningkatkan kepatuhan minum obat bagi pasien yang mengalami kesulitan dalam menelan dan menguyah obat seperti pasien lansia dan anak-anak (Greene et al., 2016). Tablet effervescent juga dapat mempercepat kerja atau onset obat karena tidak adanya proses disintegrasi dalam tubuh sehingga dapat meningkatkan proses absorbsi obat. Studi lainnya juga banyak menyebutkan tablet effervescent dapat meningkatkan penyerapan jumlah zat aktif obat dibandingkan tablet konvensional (Saifullah et al., 2016).

Kombinasi asam sitrat dan asam tartrat merupakan komponen yang mempunyai peranan penting dalam keberhasilan formulasi tablet effervescent (Anova et al., 2016). Variasi konsentrasi asam sitrat dan asam tartrat sangat berpengaruh terhadap banyaknya gas karbondioksida yang terbentuk, juga berpengaruh signifikan terhadap sifat fisik tablet effervescent (Anwar, 2010). Zat pengasam yang digunakan dalam penelitian ini yaitu kombinasi asam sitrat dan asam tartrat dikarenakan garam-garam effervescent biasanya diolah dari suatu kombinasi asam sitrat dan asam tartrat dibandingkan hanya mengggunakan zat pengasam tunggal, karena penggunaan bahan asam tunggal akan menghasilkan sediaan yang kurang stabil. Asam sitrat mempunyai sifat higroskopis yang sangat tinggi, sedangkan asam tartrat mempunyai sifat higroskopis yang lebih rendah. Apabila hanya menggunakan asam tartrat sebagai asam tunggal, serbuk effervescent yang dihasilkan akan menggumpal, menimbulkan reaksi effervescent yang terlalu dini dan sediaan yang mudah rapuh. Sedangkan asam sitrat saja akan menghasilkan 
campuran serbuk yang lekat. Kombinasi zat pengasam ditujukan untuk mempermudah proses pembuatan formulasi effervescent dan meningkatkan kelarutan tablet effervescent. Asam sitrat dan asam tartrat mempunyai kelarutan yang sangat baik dalam medium air (Ansel, 1989). Kelarutan menjadi syarat penting dalam formulasi tablet effervescent, zat aktif atau bahan dalam formulasi tablet effervescent harus mempunyai kelarutan yang baik dalam medium air untuk menimbulkan reaksi effervescent dengan cepat (Mohrle, 1989).

Kombinasi asam sitrat dan asam tartrat perlu dilakukan optimasi dengan metode Simplex Lattice Design (SLD) guna mendapatkan konsentrasi kombinasi asam sitrat dan asam tartrat yang optimal untuk tablet effervescent ekstrak ubi jalar ungu. Metode Simplex Lattice Design merupakan metode yang digunakan untuk menentukan sediaan yang paling optimal dari dua campuran atau lebih (Bolton, 1997). Metode ini merupakan metode yang paling sederhana serta lebih efektif dan efisien karena lebih murah dan tidak perlu membutuhkan banyak tenaga (Aprilianto, 20II) (Ermawati et al., 2017). Penelitian sebelumnya yang dilakukan oleh Fauzan H.A (2019) mampu mendapatkan konsentrasi kombinasi asam sitrat dan asam tartrat yang paling optimal pada formulasi tablet effervescent dengan zat aktif ekstrak buah tin menggunakan metode simplex lattice design.

Berdasarkan latar belakang tersebut, maka peneliti ingin melakukan optimasi kombinasi asam sitrat dan asam tartrat dari formulasi sediaan tablet effervescent ekstrak ubi jalar ungu dengan metode simplex lattice design (SLD).

\section{METODOLOGI}

\section{Alat dan Bahan}

Alat yang digunakan dalam penelitian ini yaitu bejana maserasi, waterbath, hotplate (Thermo Scientific), ayakan no. I8 (Siever Shake SS-200), alat-alat gelas (Pyrex), timbangan analitik (Shimadzu Corporation ATX 224), oven (Memmert), desikator, alat uji sifat alir (Granule Flow Tester GFT-I00-AU), alat uji pengetapan (Top Density Tester TDT-2-H), alat uji kerapuhan (Friability Tester TFT-2-D), alat uji kekerasan tablet (Hardness Tester).

Bahan-bahan yang digunakan dalam penelitian ini adalah ekstrak ubi jalar ungu, asam sitrat, asam tartrat, sukrosa, etanol 96\%, natrium karbonat, PEG (Polyethylen glikol) 6000, PVP I\% dan laktosa.

\section{Metode Penelitian}

\section{Pengelolaan Simplisia}

I. Pengumpulan bahan

Tanaman ubi jalar ungu diperoleh dari daerah Pelaihari, Kalimantan Selatan, bagian ubi jalar ungu diambil secara manual.

2. Sortasi basah

Sortasi basah dilakukan dengan cara memisahkan kotoran atau benda asing yang tidak diinginkan dari sampel tanaman sebelum dilakukan pencucian untuk mendapatkan sampel yang layak untuk digunakan (Wahyuni R et al., 20l4).

3. Pencucian

Pencucian dilakukan untuk menghilangkan kotoran atau benda asing yang masih menempel pada sampel tanaman. Pencucian dilakukan dengan air bersih mengalir dan dilakukan sesingkat mungkin agar zat berkhasiat dari sampel tanaman tetap terjaga (Wahyuni R et al., 20I4).

4. Perajangan

Perajangan dilakukan untuk memperkecil ukuran dan luas permukaan dari sampel tanaman sehingga akan mempermudah proses pengeringan sampel. Perajangan dilakukan cara manual yaitu dengan pisau dan alat pemotong khusus untuk mendapatkan ukuran potongan sesuai yang diinginkan (Wahyuni R et al., 20l4).

5. Pengeringan 
Pengeringan dilakukan untuk mengurangi kadar air dan menghilangkan reaksi enzimatik dari tanaman, sehingga didapatkan simplisia yang tidak mudah rusak dan dapat disimpan dalam waktu yang lama. Sampel dikeringkan di bawah sinar matahari, sampel ditutup dengan kain hitam agar tidak terkena sinar matahari langsung Pengeringan dilakukan selama kurang lebih $3 \times 24$ jam sampai didapatkan simplisa kering ubi jalar ungu (Wahyuni $\mathrm{R}$ et al., 2014).

6. Sortasi kering

Sortasi kering dilakukan untuk memisahkan kotoran atau benda asing yang masih melekat pada simplisa kering ubi jalar ungu. Sortasi kering dilakukan secara manual untuk mendapatkan simplisia kering ubi jalar ungu yang layak digunakan (Wahyuni R et al., 2014).

7. Penyimpanan

Penyimpanan simplisia kering ditujukan untuk menghindari kerusakan pada simplisia, wadah yang digunakan saat penyimpanan harus aman, tidak beracun dan tidak bereaksi dengan simplisa agar tidak menyebabkan perubahan warna, rasa dan bau pada simplisia. Simplisia yang tidak tahan panas harus disimpan dalam wadah yang mampu melindungi simplisia dari panas atau cahaya seperti aluminium foil, plastik atau botol yang berwarna gelap. Simpisia kering dapat disimpan pada suhu kamar yaitu I5-30 C (Wahyuni R et al., 20I4).

\section{Ekstraksi}

Simplisia kering ubi jalar ungu dilakukan ekstraksi dengan metode maserasi. Maserasi dilakukan selama $3 \times 24$ jam dengan pelarut etanol 96\%. Hasil maserasi kemudian diuapkan dengan menggunakan waterbath dan hotplate dengan suhu kurang lebih $50^{\circ} \mathrm{C}$ untuk mendapatkan ekstrak kental (Septiani et al., 20II). Ekstrak kental kemudian ditambahkan laktosa dengan perbandingan ekstrak : laktosa yaitu I : 4 untuk mendapatkan ekstrak kering ubi jalar ungu (Mopuri et al., 2018).

\section{Formulasi Sediaan Tablet Effervescent}

Tabel I. Formulasi sediaan tablet effervescent dengan kombinasi asam sitrat dan asam tartrat

\begin{tabular}{|c|c|c|c|c|c|c|}
\hline \multirow[t]{2}{*}{ Bahan } & \multicolumn{5}{|c|}{ Formula (mg) } & \multirow{2}{*}{$\begin{array}{l}\text { Fungsi } \\
\text { bahan }\end{array}$} \\
\hline & $\mathrm{I}$ & II & III & IV & $\mathbf{V}$ & \\
\hline $\begin{array}{l}\text { Ekstrak ubi } \\
\text { jalar ungu }\end{array}$ & 38,79 & 38,79 & 38,79 & 38,79 & 38,79 & Zat aktif \\
\hline $\begin{array}{l}\text { Natrium } \\
\text { karbonat }\end{array}$ & 147,5 & 147,5 & 147,5 & 147,5 & 147,5 & $\begin{array}{c}\text { Zat } \\
\text { pembasa }\end{array}$ \\
\hline Asam sitrat & 44,25 & 59 & 73,75 & 88,5 & 103,25 & Zat \\
\hline $\begin{array}{l}\text { Asam } \\
\text { tartrat }\end{array}$ & 103,25 & 88,5 & 73,75 & 59 & 44,25 & pengasam \\
\hline Laktosa & 155,16 & 155,16 & 155,16 & 155,16 & 155,16 & Pengisi \\
\hline PEG 6000 & 1,05 & 1,05 & 1,05 & 1,05 & 1,05 & Lubrikan \\
\hline PVP I\% & 5 & 5 & 5 & 5 & 5 & Pengikat \\
\hline Sukrosa & 5 & 5 & 5 & 5 & 5 & Pemanis \\
\hline Jumlah & 500 & 500 & 500 & 500 & 500 & \\
\hline
\end{tabular}

\section{Pencampuran Serbuk Effervescent}

Siapkan semua bahan dari masing-masing formula, ayak semua bahan dengan ayakan no. 18. Campur semua bahan dari masing-masing menggunakan mortar dan digerus sampai homogen, lakukan evaluasi sifat fisik serbuk (Pradana et al., 2015).

\section{Evaluasi Sifat Fisik Serbuk Effervescent}

I. Laju alir

Serbuk sebanyak 30 gram dituang secara perlahan ke dalam corong alir tertutup. Tutup bawah corong dibuka dan serbuk akan mengalir keluar. Waktu yang diperlukan serbuk untuk mengalir dihitung menggunakan stopwatch, kemudian catat waktunya (Patel et al., 20I2). Serbuk yang baik mempunyai kecepatan alir tidak kurang dari 10 gram/detik, artinya waktu alir granul untuk 100 gram serbuk sebaiknya tidak melebihi 10 detik (Kemenkes RI, 20I4) (British Pharmacopoeia Volume IV, 2007). 
2. Sudut diam

Pengamatan dilakukan dengan mengukur gundukan serbuk dari uji sifat alir dan menentukan sudut diam yang terbentuk antara bidang datar dengan gundukan serbuk. Tinggi dan diameter serbuk digunakan untuk menentukan sudut diam (Patel et al., 20I2). Serbuk bersifat mudah mengalir apabila memiliki sudut diam $<30^{\circ}$ (British Pharmacopoeia Volume IV, 2007).

3. Kompresibilitas

Serbuk sebanyak 30 gram dimasukkan ke dalam gelas ukur. Gelas ukur dipasang sebanyak pada alat uji pengetapan dan dihentakkan sebanyak 100 kali hentakan. Hentakan di ulang sampai volume serbuk konstan (Noval \& Rosyifa, 202I). Nilai yang didapatkan pada pengujian ini berupa indeks kompresibilitas (Anonim, 20l4). Granul atau serbuk yang mempunyai sifat alir yang baik mempunyai nilai indeks kompresibilitas $<20 \%$ (Apriyanto et al., 2017). Perhitungan nilai kompresibilitas sebagai berikut:

$$
\% C=\frac{(r k-r o)}{r k} \times 100 \%
$$

Besarnya : rk = M/Vk

$$
\text { ro }=M / \mathrm{Vo}_{0}
$$

Keterangan : $\mathbf{M}=$ berat granul atau serbuk

Vo $=$ Volume granul awal

$\mathrm{Vk}=$ volume granul setelah konstan

4. Uji kelembaban serbuk

Uji kelembaban serbuk dilakukan dengan menimbang serbuk sebanyak $500 \mathrm{mg}$ dan dimasukkan ke dalam oven, dilakukan pemanasan pada suhu $50^{\circ} \mathrm{C}$ selama 30 menit, catat hasil sebelum pemanasan dan sesudah pemanasan. Kelembaban yang baik dari tablet effervescent adalah <5\% (BPOM, 20I4). Kandungan lembab (Moisture Content) dapat dihitung dengan menggunakan rumus (Dewi, 2010) :

$$
\% M C=\frac{\text { berat air dalam sampel }}{\text { berat sampel kering }} \times 100 \%
$$

\section{Pembuatan tablet effervescent}

Pembuatan tablet effervescent dilakukan dengan metode kempa langsung. Metode kempa langsung dilakukan dengan mencampur bahan obat dengan bahan tambahan kemudian di kempa langsung pada mesin pencetak tablet. Campuran serbuk effervescent yang sudah dievaluasi dimasukkan ke dalam mesin pencetak tablet, setelah didapatkan sediaan tablet lakukan evaluasi fisik tablet (Pradana et al., 20I5).

\section{Evaluasi sifat fisik tablet effervescent}

I. Organoleptik

Pengamatan organoleptis dilakukan dengan mengamati bentuk, bau, rasa dan warna tablet (BPOM, 20I4) (Noval et al., 2020).

2. Keseragaman bobot

Timbang 20 tablet satu per satu kemudian dicatat bobotnya pada timbangan analitik. Semakin kecil perbedaan bobot, semakin seragam sediaan tablet yang dihasilkan (Anonim, 2016). Setelah didapatkan nilai rata-rata tablet, hitung nilai Standar Deviasi (SD) dan \% Koefisien Variasi (CV). Tablet yang seragam memiliki nilai CV tidak lebih dari 5\% (Kemenkes RI, 20I4) (Alawiyah, 2012).

Tabel 2. Keseragaman bobot tablet (Anonim,

1979)

\begin{tabular}{ccc}
\hline \multirow{2}{*}{ Bobot rata-rata } & $\begin{array}{c}\text { Penyimpangan } \\
\text { Bobot Rata-Rata } \\
\text { (\%) }\end{array}$ & $\begin{array}{c}\text { Penyimpangan } \\
\text { Bobot Rata-Rata }\end{array}$ \\
\cline { 2 - 3 } & A & (\%) \\
\hline $25 \mathrm{mg}$ atau kurang & $15 \%$ & $\mathbf{B}$ \\
\hline $\begin{array}{c}26 \mathrm{mg} \text { sampai I50 } \\
\mathrm{mg}\end{array}$ & $10 \%$ & $30 \%$ \\
\hline $\begin{array}{c}15 \mathrm{I} \mathrm{mg} \mathrm{sampai} 300 \\
\mathrm{mg}\end{array}$ & $7,5 \%$ & $20 \%$ \\
\hline Lebih dari $300 \mathrm{mg}$ & & $15 \%$ \\
\hline
\end{tabular}

3. Kekerasan tablet

Siapkan 5 tablet, lakukan pengujian kekerasan dengan menggunakan alat hardness tester. Nilai kekerasan akan muncul pada alat dalam satuan 
$\mathrm{kg} / \mathrm{cm}^{2}$. Kekerasan tablet yang diperkenankan adalah $4-8 \mathrm{~kg} / \mathrm{cm}^{2}$ ( Alawiyah, 2012).

4. Kerapuhan tablet

Siapkan 10 tablet bebas debu, tablet ditimbang dan dimasukkan ke dalam alat friability tester. Alat diputar pada kecepatan 25 putaran per menit selama 4 menit. Bersihkan debu dari tablet dan timbang kembali, hitung nilai kerapuhan tablet. Kerapuhan tablet dinyatakan dalam bentuk persen (Anonim, 2016). Kerapuhan tablet yang masih dapat diterima yaitu <1\% (Voight, 1994). Kerapuhan di atas $1 \%$ menunjukkan tablet yang rapuh dan dianggap kurang baik (Banker et al., 1986).

$$
\% \text { kerapuhan }=\frac{w 1-w 2}{w 1} \times 100 \%
$$

Keterangan $: \mathrm{wI}=$ bobot granul awal

$$
\text { w2 = bobot granul akhir }
$$

\section{Waktu larut}

Siapkan 5 tablet dari masing-masing formula masukkan ke dalam gelas yang berisi air $200 \mathrm{ml}$, lakukan perhitungan waktu larut tablet menggunakan stopwatch terhitung dari pertama kali tablet masuk ke dalam air hingga telarut sempurna (Aslani \& Daliri, 2016). Tablet effervescent yang baik akan larut dan hancur dengan rentang waktu I-2 menit (Mohrle, 1989). Teori lain juga ada yang menyebutkan waktu larut yang baik untuk tablet effervescent yaitu kurang dari 5 menit (BPOM, 2014).

\section{HASIL DAN PEMBAHASAN}

\section{Simplisia dan Ekstraksi Maserasi}

Pengelolaan simplisia ubi jalar ungu yang diawali dengan pengumpulan bahan, sortasi basah, pencucian, perajangan, dan dilakukan pengeringan di bawah sinar matahari. Simplisia ditutup dengan kain hitam agar tidak terkena sinar matahari langsung. Setelah didapatkan simplisia kering dilakukan kembali sortasi kering untuk memisahkan benda asing yang melekat pada simplisia dan selanjutnya dilakukan penyimpanan simplisia. Berdasarkan hasil pengelolaan simplisia dari 10 kg ubi jalar ungu didapatkan I,7 kg simplisia kering ubi jalar ungu.

Ekstraksi simplisia ubi jalar ungu (Ipomoea batatas L) dilakukan dengan metode maserasi selama $3 \times 24$ jam dengan menggunakan pelarut etanol $96 \%$ dapat dilihat pada tabel 3 di bawah.

Tabel 3. Hasil ekstraksi ubi jalar ungu (Ipomoea batatas L)

\begin{tabular}{ccc}
\hline Simplisia + etanol 96\% & $\begin{array}{c}\text { Ekstrak } \\
\text { cair }\end{array}$ & $\begin{array}{c}\text { Ekstrak } \\
\text { kental }\end{array}$ \\
\hline $1,7 \mathrm{~kg}+20 \mathrm{~L}$ & $18 \mathrm{~L}$ & $293,15 \mathrm{~g}$ \\
\hline
\end{tabular}

Ekstrak cair ubi jalar ungu dipanaskan menggunakan waterbath dan hotplate karena lebih murah dan efisien, proses pemanasan tetap dilakukan pemantauan pada suhu kurang lebih $50^{\circ} \mathrm{C}$ agar senyawa yang terkandung pada ekstrak tidak mengalami penguraian. Ekstrak kental ubi jalar ungu diperoleh sebanyak 293,15 gram, kemudian ekstrak kental ubi jalar ungu dibuat menjadi ekstrak kering dengan penambahan laktosa I : 4, selanjutnya semua bahan pada formulasi tablet effervescent dicampurkan dan dilakukan evaluasi serbuk effervescent (Mopuri et al., 2018)

Hasil dan Pembahasan Evaluasi Serbuk Effervescent

Tablet effervescent merupakan sediaan tablet yang mengandung zat basa dan zat asam yang membentuk suatu karbondioksida yang berperan dalam proses pelarutan tablet dalam suatu larutan (Fauzan H.A, 2019). Penelitian ini dilakukan dengan melakukan kombinasi dan variasi zat pengasam yaitu asam sitrat dan asam tartrat untuk mengetahui pengaruhnya terhadap evaluasi tablet effervescent dengan zat aktif ekstrak ubi jalar ungu. Evaluasi serbuk effervescent meliputi uji laju alir, sudut diam, kompresibilitas dan kelembaban serbuk. 
I. Uji laju alir

Tabel 4. Hasil laju alir serbuk effervescent

\begin{tabular}{cc}
\hline Formulasi & Laju alir (detik) \\
\hline FI & 3 \\
\hline F2 & 3 \\
\hline F3 & 3 \\
\hline F4 & 3 \\
\hline F5 & 3
\end{tabular}

Uji laju alir dilakukan untuk mengetahui kualitas dari serbuk effervescent, dimana hal tersebut berpengaruh dalam proses pencetakan tablet, laju alir yang baik membuat serbuk mudah mengalir serbuk sehingga tablet yang dihasilkan akan mempunyai keseragaman yang baik. Uji laju alir ini dilakukan dengan melihat waktu dan kecepatan mengalir dari serbuk effervescent. Laju alir yang baik mempunyai kecepatan alir tidak kurang dari 10 g/detik (Elisabeth et al., 2018). Berdasarkan tabel 4 hasil yang didapatkan menunjukkan hasil uji laju alir pada FI, F2, F3, F4 dan F5 memiliki laju alir yang baik dan memenuhi persyaratan dimana untuk serbuk 30 gram membutuhkan kecepatan alir selama 3 detik. Menurut persyaratan, waktu alir yang baik tidak kurang dari 10 g/detik (Elisabeth et al., 2018). Laju alir yang baik disebabkan oleh ukuran partikel yang seragam, sehingga serbuk effervescent dapat mengalir dengan baik. Pada penelitian, serbuk effervescent diayak menggunakan ayakan mesh nomor 18 untuk meningkatkan keseragaman ukuran partikel dengan tujuan memperbaiki laju alir yang dihasilkan.

Penggunaan PVP konsentrasi I\% sebagai bahan pengikat pada formulasi juga berperan dalam meningkatkan ukuran dari partikel sehingga akan menurunkan gaya kohesi dan menghasilkan laju alir yang lebih baik (Wicjaksono A.A, 2020). Laju alir juga ditentukan oleh derajat sudut diam dan nilai kompresibilitas, semakin kecil sudut diam maka semakin baik pula laju alir serbuk (Lynatra $C$ et al., 2018). Adapun pengaruh nilai kompresibilitas yaitu semakin kecil nilai kompresibilitas maka semakin baik laju alir serbuk (Apriyanto et al., 2017).

Hasil pengujian laju alir sesuai dengan penelitian (Gusmayadi I et al., 20I8) yang melakukan optimasi zat pengasam pada tablet effervescent dari ekstrak memiliki laju alir 5 detik untuk $50 \mathrm{~g}$ granul, laju alir yang dihasilkan termasuk ke dalam kategori laju alir yang baik.

2. Uji sudut diam

Tabel 5. Hasil evaluasi sudut diam serbuk effervescent

\begin{tabular}{cc}
\hline Formulasi & Sudut diam ( ) \\
\hline FI & 34,99 \\
\hline F2 & 36 \\
\hline F3 & 30,39 \\
\hline F4 & 28,81 \\
\hline F5 & 28,21 \\
\hline
\end{tabular}

Uji sudut diam pada penelitian dilakukan untuk menggambarkan laju alir serbuk effervescent, serbuk dengan nilai sudut diam lebih besar menggambarkan kemampuan laju alir yang lebih rendah dibandingkan dengan serbuk dengan nilai sudut diam lebih kecil yang mempunyai kemampuan laju alir yang lebih baik (Khaidir et al., 20I5). Sudut diam yang baik berada pada rentang $25^{\circ}-45^{\circ}$ atau kurang dari $42^{\circ}$ (Rori et al., 2016).

Hasil pengujian sudut diam serbuk effervescent pada tabel 5 setiap formula sudah memenuhi persyaratan, dimana hasil menunjukkan nilai sudut diam FI yaitu $34,99^{\circ}, \mathrm{F} 2$ yaitu $36^{\circ}, \mathrm{F} 3$ yaitu $30,39^{\circ}$, F4 yaitu $28,81^{\circ}$ dan F5 yaitu $28,21^{\circ}$. Semua formula memenuhi persyaratan, namun formula yang paling baik yaitu F5 karena memiliki sudut diam paling rendah dari rentang persyaratan sudut diam yaitu $25^{\circ}-45^{\circ}$. Hasil tersebut sesuai dengan penelitian (Fauzan H.A, 2019) yang melakukan optimasi formula kombinasi zat pengasam pada tablet effervescent dari ekstrak menunjukkan hasil pengujian sudut diam dengan rentang $29^{\circ}-33^{\circ}$, hasil terbaik pada formula F5 yaitu $29,59^{\circ}$ yang 
menggunakan konsentrasi asam sitrat tertinggi dibanding formula lain.

3. Uji kompresibilitas

Tabel 6. Hasil kompresibilitas serbuk effervescent

\begin{tabular}{cc}
\hline Formulasi & Kompresibilitas (\%) \\
\hline FI & 9,44 \\
\hline F2 & 6,67 \\
\hline F3 & 9,44 \\
\hline F4 & 8,19 \\
\hline F5 & 4 \\
\hline
\end{tabular}

Uji kompresibilitas bertujuan untuk menggambarkan sifat serbuk effervescent stabil dan kompak saat diberi tekanan pada proses pencetakan tablet, nilai kompresibilitas $<20 \%$ memiliki daya kompresibilitas yang baik, semakin kecil nilai kompresibilitas serbuk semakin baik kemampuan mengalir serbuk (Apriyanto et al., 2017). Hasil pengujian kompresibilitas pada tabel 6 menunjukkan setiap formula memenuhi persyaratan daya kompresibilitas yang baik, dimana hasil menunjukkan nilai kompresibilitas FI yaitu 9,44\%, F2 yaitu 6,67\%, F3 yaitu 9,44\%, F4 yaitu 8, 19 dan F5 yaitu $4 \%$.

Semua hasil uji memenuhi persyaratan, namun formula yang paling baik yaitu F5 karena hasil uji F5 memiliki nilai kompresibilitas terkecil yaitu $4 \%$, semakin kecil nilai kompresibilitas maka semakin baik kemampuan serbuk untuk mengalir. Berdasarkan penelitian (Lynatra $C$ et al., 2018) yang juga membuat formulasi tablet effervescent dari ekstrak dengan nilai kompresibilitas dengan rentang 12-16\%, hasil tersebut menunjukkan serbuk memiliki kompresibilitas yang baik.

Nilai kompresibilitas dapat dipengaruhi oleh sudut diam, bentuk, kerapatan dan ukuran granul. Sesuai dengan hasil pengujian sudut diam sebelumnya yang menunjukkan nilai sudut diam terkecil pada F5 yaitu $28,21^{\circ}$ menghasilkan nilai kompresibilitas yang kecil pula. Serbuk dengan ukuran partikel lebih kecil memiliki kerapatan yang lebih besar daripada serbuk dengan ukuran partikel yang lebih besar (Murtini \& Yetri, 20I8). Serbuk yang mempunyai bentuk dan ukuran granul seragam akan mempermudah serbuk dalam proses pengempaan sehingga akan menghasilkan tablet effervescent yang baik (Bejugam et al., 20I5).

4. Uji kelembaban serbuk

Tabel 7. Hasil kelembaban serbuk effervescent

\begin{tabular}{cccc}
\hline Formulasi & $\begin{array}{c}\text { Bobot } \\
\text { sebelum } \\
\text { pengeringan } \\
(\mathrm{mg})\end{array}$ & $\begin{array}{c}\text { Bobot } \\
\text { sebelum } \\
\text { pengeringan } \\
(\mathrm{mg})\end{array}$ & \%MC \\
\hline FI & 500 & 486 & 2,88 \\
\hline F2 & 500 & 486 & 2,88 \\
\hline F3 & 500 & 495 & $\mathrm{I}, 0 \mathrm{I}$ \\
\hline F4 & 500 & 493 & $\mathrm{I}, 4 \mathrm{I}$ \\
\hline F5 & 500 & 494 & $\mathrm{I}, 2 \mathrm{I}$ \\
\hline
\end{tabular}

Uji kelembaban serbuk atau Moisture Content dilakukan untuk mengetahui kandungan lembab pada serbuk effervescent setelah mengalami proses pengeringan. Serbuk yang mempunyai kandungan lembab terlalu tinggi akan meningkatkan resiko serbuk melekat pada punch atau pencetak tablet, semakin tinggi kelembaban serbuk maka akan semakin meningkatkan resiko reaksi effervescent yang terlalu dini sehingga akan menghasilkan tablet yang kurang stabil. Kandungan lembab yang baik pada tablet effervescent adalah $\leq 5 \%$ (BPOM, 20I4).

Hasil pengujian Moisture Content pada setiap formula memenuhi persyaratan, dimana hasil pengujian menunjukkan nilai Moisture Content FI dan F2 yaitu 2,88\%, F3 yaitu I,0I\%, F4 yaitu I,4I\% dan F5 yaitu I,21\%. Semua formula memenuhi persyaratan kandungan lembab yang baik, namun formula yang paling baik yaitu F3 karena hasil pengujian menunjukkan nilai yang jauh dari batas syarat kandungan lembab serbuk yaitu 5\% dengan formulasi perbandingan asam sitrat dan asam tartrat yang sama yaitu 50:50. Hasil ini sesuai dengan penelitian (Kartikasari et al., 20I5) tentang formulasi tablet effervescent dengan kombinasi asam sitrat dan asam tartrat juga memiliki kandungan lembab yang rendah yaitu $1,22 \%$ dengan perbandingan asam sitrat dan asam tartrat yang sama pula. 


\section{Hasil dan Pembahasan Evaluasi Tablet}

\section{Effervescent}

Pembuatan tablet dilakukan dengan metode kempa langsung, dimana serbuk effervescent dari tiap formula yang sudah dilakukan evaluasi ditimbang satu persatu dengan bobot $500 \mathrm{mg}$ dan kemudian dicetak langsung pada mesin pencetak tablet (Noval et al., 202I) (Pradana et al., 2015). Tablet yang dihasilkan pada tiap formula adalah 30 tablet effervescent, dengan total keseluruhan tablet yaitu 150 tablet effervescent. Tablet effervescent pada tiap formula dilakukan evaluasi tablet meliputi evaluasi organoleptik, keseragaman bobot, kerapuhan tablet, kekerasan tablet dan waktu larut tablet. Proses evaluasi dilakukan untuk menjamin bahwa tablet sesuai dengan ketentuan persyaratan tablet yang baik.

I. Uji organoleptik

Tabel 8. Hasil evaluasi organoleptis tablet

\begin{tabular}{|c|c|c|c|c|}
\hline \multirow{2}{*}{ Formula } & \multicolumn{4}{|c|}{ Pemeriksaan organoleptis } \\
\hline & Bentuk & Bau & Rasa & Warna \\
\hline $\mathrm{FI}$ & $\begin{array}{l}\text { Bulat } \\
\text { pipih }\end{array}$ & Manis & $\begin{array}{c}\text { Sedikit } \\
\text { pahit }\end{array}$ & $\begin{array}{c}\text { Coklat } \\
\text { kombinasi } \\
\text { putih }\end{array}$ \\
\hline F2 & $\begin{array}{l}\text { Bulat } \\
\text { pipih }\end{array}$ & Manis & $\begin{array}{c}\text { Sedikit } \\
\text { pahit }\end{array}$ & $\begin{array}{c}\text { Coklat } \\
\text { kombinasi } \\
\text { putih }\end{array}$ \\
\hline F3 & $\begin{array}{l}\text { Bulat } \\
\text { pipih }\end{array}$ & Manis & $\begin{array}{c}\text { Sedikit } \\
\text { pahit }\end{array}$ & $\begin{array}{c}\text { Coklat } \\
\text { kombinasi } \\
\text { putih }\end{array}$ \\
\hline $\mathrm{F} 4$ & $\begin{array}{l}\text { Bulat } \\
\text { pipih }\end{array}$ & Manis & $\begin{array}{c}\text { Sedikit } \\
\text { pahit }\end{array}$ & $\begin{array}{c}\text { Coklat } \\
\text { kombinasi } \\
\text { putih }\end{array}$ \\
\hline F5 & $\begin{array}{l}\text { Bulat } \\
\text { pipih }\end{array}$ & Manis & $\begin{array}{c}\text { Sedikit } \\
\text { pahit }\end{array}$ & $\begin{array}{c}\text { Coklat } \\
\text { kombinasi } \\
\text { putih }\end{array}$ \\
\hline
\end{tabular}

Uji organoleptik tablet meliputi pengamatan bentuk, warna, rasa dan bau tablet (Noval et al., 2020). Secara umum, keseluruhan tablet effervescent ekstrak ubi jalar ungu memiliki karakter fisik yang seragam, dengan bentuk bulat pipih, berwarna coklat dengan kombinasi putih, rasa sedikit pahit dan berbau manis. Tablet yang dihasilkan berbentuk bulat pipih disebabkan bentuk punch pencetak tablet yang berbentuk bulat. Warna coklat dengan kombinasi putih berasal dari ekstrak ubi jalar ungu dan warna putih berasal dari campuran bahan tambahan. Rasa pahit yang disebabkan oleh berbagai campuran dari bahan tambahan dan berbau manis karena adanya bahan tambahan sukrosa pada formula tablet effervescent.

Berdasarkan penelitian (Fauzan H.A, 2019) yang melakukan optimasi formula tablet effervescent dari ekstrak menghasilkan karakter fisik tablet yang seragam yaitu berwarna kecoklatan dan kekuningan disebabkan warna dari ekstrak dan bahan tambahan yang digunakan. Penelitian lainnya juga dilakukan oleh (Hakim A.R, 2019) dengan formulasi tablet effervescent dari ekstrak menghasilkan sediaan tablet effervescent berwarna coklat dengan butiran putih disebabkan oleh ekstrak dan bahan tambahan pada campuran sediaan.

2. Keseragaman bobot tablet

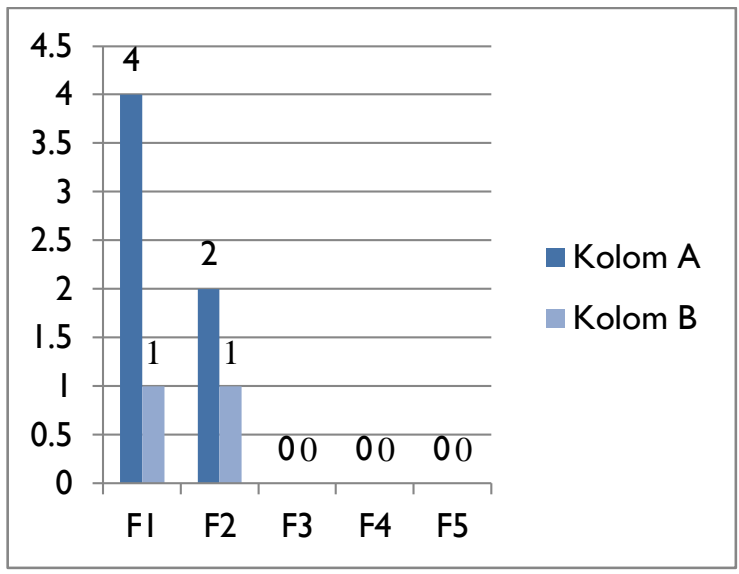

Gambar I. Hasil penyimpangan evaluasi keseragaman bobot tablet

Tabel 9. Hasil koefisien variasi keseragaman bobot tablet

\begin{tabular}{cccc}
\hline Formula & Nilai X & $\begin{array}{c}\text { Nilai } \\
\text { SD }\end{array}$ & \%CV \\
\hline FI & 473,165 & $\mathrm{I} 4,896$ & 3,14 \\
\hline F2 & 480,57 & 17,090 & 3,55 \\
\hline F3 & $48 \mathrm{I}, 685$ & 6,308 & $\mathrm{I}, 30$ \\
\hline F4 & $488, \mathrm{II}$ & $7,92 \mathrm{I}$ & $\mathrm{I}, 62$ \\
\hline F5 & $49 \mathrm{I}, 2$ & 5,109 & $\mathrm{I}, 04$ \\
\hline
\end{tabular}

Uji keseragaman bobot bertujuan untuk mengetahui keseragaman kandungan zat aktif pada tiap tablet yang 
akan berhubungan dengan efek terapi yang dihasilkan (Ainurofiq \& Azizah, 2016). Keseragaman bobot ditunjukkan dengan banyaknya penyimpangan tablet dari persyaratan yang ditentukan dan dilihat dari nilai \% Koefisien Variasi (CV). Standar penyimpangan tablet dengan rata-rata bobot $500 \mathrm{mg}$ yaitu kolom A 5\% dan kolom B 10\%, dimana menurut persyaratan Farmakope Edisi III artinya tidak boleh lebih dari 2 tablet yang menyimpang dari kolom A dan tidak boleh ada I pun tablet yang menyimpang dari kolom B (Anonim, 1979). Nilai \% CV digunakan untuk menentukan berat tablet konstan atau tidak, semakin kecil nilai CV maka semakin seragam berat tablet pada tiap formula. Tablet yang seragam memiliki nilai CV $<5 \%$ (Kemenkes RI, 2014) (Alawiyah, 20I2). Hasil perhitungan keseragaman bobot tablet effervescent pada FI dan F2 terdapat penyimpangan bobot tablet, pada FI terdapat 4 tablet yang menyimpang dari kolom A dan I tablet menyimpang dari kolom B, pada F2 terdapat 2 tablet yang menyimpang dari kolom A dan I tablet yang menyimpang dari kolom $B$ menunjukkan hasil tersebut tidak memenuhi persyaratan.

Adapun pada F3, F4 dan F5 memenuhi persyaratan bobot tablet. Hasil keseragaman bobot tablet juga dapat dilihat pada nilai \%CV bahwa F3, F4 dan F5 yaitu dengan nilai \%CV berturut-turut I,30\%, I,62\%, dan I,04\%. Adapun pada FI dan F2 meskipun nilai \%CV masih di bawah $5 \%$ tapi tetap mendekati batas ketentuan $5 \%$ yaitu berada pada nilai \%CV berturutturut yaitu 3,14 dan 3,55\%, dimana secara umum nilai \%CV masih memenuhi persyaratan yaitu di bawah $5 \%$, namun tetap terdapat penyimpangan bobot tablet pada FI dan F2 berdasarkan perhitungan keseragaman bobot tablet Farmakope Edisi III.

Berdasarkan hasil evaluasi keseragaman bobot tablet, formula yang paling baik yaitu F5 karena \%CV yang didapat lebih rendah dibandingkan formula lain, semakin rendah nilai \%CV pada F5 menunjukan tingginya keseragaman bobot tablet pada formulasi tersebut. Faktor penyimpangan bobot tablet bisa disebabkan karena adanya penyimpangan berat serbuk sehingga pada proses pencetakan tablet, serbuk yang dimasukkan ke dalam alat pencetak jumlahnya berbeda, hal tersebut menyebabkan bobot tablet yang dihasilkan akan tidak seragam (Wicjaksono, 2020). Adapun dari pengujian yang dilakukan, bobot tiap tablet sebelum dilakukan pencetakan sudah ditimbang terlebih dahulu, sehingga penyebab penyimpangan bobot tablet dari hasil penelitian dikarenakan ketidakseragaman bobot tablet pada saat proses pencetakan tablet, dimana sebagian bobot tablet menempel pada lubang die menyebabkan bobot tablet yang dihasilkan tidak memenuhi persyaratan (Kholidah et al., 20I4).

3. Kekerasan tablet

Tabel 10. Hasil evaluasi kekerasan tablet

\begin{tabular}{cc}
\hline Formula & Kekerasan $(\mathrm{kg})$ \\
\hline FI & 4,2 \\
\hline F2 & 4 \\
\hline F3 & 3,5 \\
\hline F4 & $3, \mathrm{I}$ \\
\hline F5 & $3, \mathrm{I}$ \\
\hline
\end{tabular}

Uji kekerasan tablet dilakukan untuk menggambarkan kekuatan atau ketahanan tablet dari benturan atau tekanan mekanik saat proses produksi hingga distribusi obat (Fauzan H.A, 2019). Kekerasan tablet yang baik berada pada rentang 4-8 kg/cm (Apsari et al., 20l8). Berdasarkan hasil pengujian pada tabel 10 menunjukkan nilai kekerasan FI yaitu $4,2 \mathrm{~kg}$, F2 yaitu 4 kg, F3 yaitu 3,5 kg, F4 dan F5 yaitu 3, I kg. Berdasarkan hasil tersebut dapat dilihat bahwa FI dan F2 memenuhi persyaratan kekerasan tablet yang baik. Adapun F3, F4 dan F5 tidak memenuhi persyaratan karena nilai kekerasan tablet yang dihasilkan tidak sesuai dengan rentang kekerasan tablet yang baik. Berdasarkan hasil uji kekerasan tablet formula yang paling baik yaitu FI karena berada pada rentang persyaratan kekerasan tablet yang tidak terlalu rendah maupun terlalu tinggi yaitu $4,2 \mathrm{~kg}$.

Kekerasan tablet dipengaruhi oleh bahan pengikat, bahan pengikat yang digunakan pada formulasi yaitu 
PVP dengan konsentrasi I\%, konsentrasi PVP yang digunakan sebagai bahan pengikat berkisar 0,5-5\%. Bahan pengikat PVP jika dicampurkan dengan serbuk yang higroskopis atau kandungan lembab yang lebih tinggi maka akan meningkatkan kekerasan tablet disebabkan karena meningkatnya daya ikatan antar partikel, formulasi FI dan F2 juga memiliki kandungan lembab yang lebih tinggi sehingga kekerasan tablet juga akan semakin tinggi (Putri \& Husni, 2018). Faktor lainnya yang berpengaruh terhadap kekerasan tablet yaitu tekanan kompresi saat proses pencetakan, semakin besar tekanan yang diberikan saat proses pencetakan maka kekerasan tablet juga akan semakin meningkat (Syamsia et al., 2017).

Pengaruh konsentrasi asam sitrat dan asam tartrat terhadap kekerasan tablet yaitu asam sitrat lebih berpengaruh dalam menentukan kekerasan tablet dibandingkan asam tartrat, ikatan asam sitrat dengan satu molekul air akan lebih kuat dibandingkan asam tartrat sehingga asam sitrat akan memberikan kekerasan tablet yang lebih baik. Asam sitrat dan asam tartrat memiliki pengaruh terhadap kekerasan tablet (Kartikasari et al., 20I5). Hasil tersebut sesuai dengan penelitian (Fauzan H.A, 2019) tentang optimasi zat pengasam pada tablet effervescent dengan nilai kekerasan tablet pada F5 sebesar $8 \mathrm{~kg}$, dimana formula tersebut memiliki konsentrasi asam sitrat lebih tinggi dibandingkan formula lainnya.

4. Kerapuhan tablet

Tabel II. Hasil evaluasi kerapuhan tablet

\begin{tabular}{cccc}
\hline Formula & $\begin{array}{c}\text { Bobot } \\
\text { awal } \\
(\mathrm{mg})\end{array}$ & $\begin{array}{c}\text { Bobot } \\
\text { akhir } \\
(\mathrm{mg})\end{array}$ & $\begin{array}{c}\text { Kerapuhan } \\
(\%)\end{array}$ \\
\hline FI & $4.772,2$ & $4.765,6$ & 0,13 \\
\hline F2 & $4.813,0$ & $4.804,0$ & 0,18 \\
\hline F3 & $4.843,0$ & $4.816,3$ & 0,55 \\
\hline F4 & $4.905, \mathrm{I}$ & $4.901,6$ & 0,07 \\
\hline F5 & $4.917,2$ & $4.912,8$ & 0,08 \\
\hline
\end{tabular}

Uji kerapuhan tablet bertujuan untuk mengetahui ketahanan tablet dalam mempertahankan fisiknya terhadap gangguan mekanik, kerapuhan tablet yang dapat diterima yaitu kurang dari $1 \%$ (Yulianti \& Sutoyu S, 202I). Berdasarkan tabel 4.12 menunjukkan nilai kerapuhan $\mathrm{FI}$ yaitu $0,13 \%, \mathrm{~F} 2$ yaitu $0,18 \%$, F3 yaitu $0,55 \%$, F4 yaitu $0,07 \%$ dan F5 yaitu $0,08 \%$, hasil tersebut menunjukkan semua formula sudah memenuhi persyaratan kerapuhan tablet yang baik yaitu di bawah I\% (Yulianti \& Sutoyu S, 202I). Namun yang paling baik yaitu formula F4 karena nilai kerapuhan tablet yang dihasilkan lebih rendah dibandingkan dengan formula lain yaitu $0,07 \%$.

Kerapuhan tablet dipengaruhi oleh kandungan lembab, selaras dengan hasil pengujian kandungan lembab pada F3 sebesar I,0I\% menghasilkan tablet dengan nilai kerapuhan yang lebih tinggi pula dibandingkan formula lain, hal tersebut disebabkan karena semakin rendah kandungan lembab tablet maka kerapuhan tablet akan meningkat dikarenakan lemahnya daya ikat antar partikel tablet (Syukri et al., 2018). Pengaruh asam sitrat dan asam tartrat terhadap kerapuhan tablet yaitu asam tartrat lebih berpengaruh dominan terhadap kerapuhan tablet, dimana asam tartrat memiliki efek yang lebih besar dari interaksi asam sitrat dan asam tartrat. Hasil penelitian (Kartikasari et al., 2015) tentang formulasi tablet effervescent kombinasi asam sitrat dan asam tartrat dengan kandungan lembab yang paling rendah pada $\mathrm{FI}$ sebesar I,03\% menghasilkan tablet dengan kerapuhan yang tinggi pula yaitu $0,98 \%$, namun hasil tersebut masih sesuai batas persyaratan kerapuhan tablet yang baik.

5. Waktu larut tablet

Tabel 12. Hasil evaluasi waktu larut tablet

\begin{tabular}{cc}
\hline Formula & Waktu larut (Menit) \\
\hline FI & 03.69 \\
\hline F2 & 03.43 \\
\hline F3 & 04.53 \\
\hline F4 & 03.45 \\
\hline F5 & 02.58 \\
\hline
\end{tabular}

Uji waktu larut tablet bertujuan untuk mengetahui waktu yang diperlukan tablet untuk larut dalam suatu larutan. Waktu larut yang baik untuk tablet effervescent 
yaitu kurang dari 5 menit (BPOM, 20I4). Berdasarkan hasil pengujian pada tabel 4. 14 menunjukkan waktu larut FI yaitu 03.69 menit, F2 yaitu 03.43 menit, F3 yaitu 04.53 menit, F4 yaitu 03.45 menit dan F5 yaitu 02.58 menit. Semua hasil pengujian memenuhi persyaratan yaitu kurang dari 5 menit. Namun, dari hasil pengujian waktu larut formula yang paling baik yaitu F5 karena waktu larut yang dihasilkan lebih cepat dibandingkan formula lain yaitu 02.58 menit, semakin cepat tablet effervescent larut maka akan semakin baik (BPOM, 20I4). Hal tersebut dikarenakan tingginya konsentrasi asam sitrat pada formula F5 dengan perbandingan asam sitrat dan asam tartrat yaitu sebesar 70:30, asam sitrat berpengaruh lebih dominan dibandingkan asam tartrat terhadap proses pelarutan tablet, efek asam sitrat lebih besar dibandingkan asam tartrat saat proses interaksi keduaya. Selain itu, asam sitrat juga memiliki sifat yang lebih higroskopis sehingga lebih mudah larut air dibandingkan asam tartrat sehingga proses pelarutan akan berlangsung lebih cepat (Hakim A.R, 2019).

Waktu larut tablet effervescent juga dipengaruhi oleh kekerasan tablet, dimana hasil penelitian pada F5 memiliki nilai kekerasan lebih rendah yaitu $3,1 \mathrm{~kg}$ sehingga proses pelarutan tablet dapat berlangsung lebih cepat. Proses pelarutan tablet diawali dengan masuknya air ke dalam pori-pori tablet karena adanya sifat hidrofilik dari PVP sebagai bahan pengikat yang mempermudah masuknya air ke dalam pori-pori tablet. Masuknya air ke dalam pori-pori tablet menimbulkan reaksi effervescent antara asam dan karbonat yang melepaskan karbondioksida untuk proses pelarutan tablet effervescent. Hasil penelitian sesuai dengan penelitian (Lynatra C et al., 2018) dengan formulasi tablet effervescent dari ekstrak pada FI memiliki nilai kekerasan tablet terendah yaitu 5,17 kg menghasilkan nilai waktu larut tercepat pula yaitu 02.37 menit. Hasil penelitian lainnya juga dilakukan (Kumala Sari et al., 2018) tentang optimasi sediaan tablet effervescent dengan nilai kekerasan tablet yang lebih rendah pada
FI yaitu 2,2 kg juga memiliki waktu larut yang lebih cepat yaitu 84,7 detik.

Kombinasi asam sitrat dan asam tartrat sebagai zat pengasam terhadap formulasi tablet effervescent ekstrak ubi jalar ungu berdasarkan evaluasi fisik tablet yang sudah dilakukan yaitu pada evaluasi kekerasan tablet menunjukkan asam sitrat lebih berpengaruh dominan dalam kekerasan tablet, dimana dapat dilihat pada FI menghasilkan nilai kekerasan tablet yang lebih baik dibandingkan formula lain. Evaluasi kerapuhan tablet juga dipengaruhi oleh kombinasi asam sitrat dan asam tartrat, asam tartrat lebih dominan berpengaruh dalam menentukan kerapuhan tablet. Hasil formulasi F4 menunjukkan penggunaan asam tartrat konsentrasi rendah memiliki nilai kerapuhan yang lebih baik, dimana asam tartrat dengan konsentrasi yang rendah akan menyebabkan penurunan nilai kerapuhan dari tablet effervesecent.

Adapun pada evaluasi waktu larut yang merupakan parameter utama dalam sediaan tablet effervescent, penggunaan asam sitrat lebih berpengaruh dominan terhadap waktu larut tablet dikarenakan sifat asam sitrat yang lebih higroskopis menyebabkan proses pelarutan tablet juga berlangsung lebih cepat, pada hasil evaluasi formula $\mathrm{FI}$ menggunakan perbandingan konsentrasi asam sitrat dan asam tartrat 30:70, F2 yaitu perbandingan 40:60, F3 yaitu perbandingan 50:50, F4 yaitu perbandingan 60:40 dan F5 dengan perbandingan 70:30, sehingga dapat tergambarkan pada formula F5 dengan penggunaan konsentrasi asam sitrat yang lebih tinggi menghasilkan waktu larut tablet effervescent yang lebih cepat dibandingkan formula lain. Berdasarkan hal tersebut, kombinasi dari asam sitrat dan asam tartrat berpengaruh terhadap evaluasi fisik tablet effervescent yang dihasilkan (Kartikasari et al., 20I5).

Optimasi Kombinasi Asam Sitrat dan Asam Tartrat pada Formula Tablet Effervescent Ekstrak Ubi Jalar Ungu 
Optimasi kombinasi asam sitrat dan asam tartrat pada tablet effervescent ekstrak ubi jalar ungu dilakukan dengan metode simplex lattice design dengan software design expert versi 10.0. Langkah pertama optimasi yaitu penentuan komponen yang akan divariasikan yaitu asam sitrat $(X I)$, asam tartrat $(X 2)$ dan respon (Y) yang digunakan yaitu kekerasan tablet, kerapuhan tablet dan waktu larut tablet. Selanjutnya proses optimasi dilakukan dengan penetapan batas atas dan batas bawah dari masing-masing komponen untuk mengetahui rentang nilai yang digunakan dari asam sitrat dan asam tartrat (Fauzan H.A., 2019).

Tabel 12. Batas penggunaan asam sitrat dan asam tartrat

\begin{tabular}{ccc}
\hline Komponen & $\begin{array}{c}\text { Batas Bawah } \\
\text { (dalam sediaan } 500 \\
\mathrm{mg})\end{array}$ & $\begin{array}{c}\text { Bawah Atas } \\
\text { (dalam sediaan 500 } \\
\mathrm{mg})\end{array}$ \\
\hline Asam Sitrat & $44,25 \mathrm{mg}$ & $103,25 \mathrm{mg}$ \\
\hline Asam Tartrat & $44,25 \mathrm{mg}$ & $103,25 \mathrm{mg}$ \\
\hline
\end{tabular}

\section{Penentuan Formula Optimal}

Penentuan formula optimal dilakukan dengan tujuan untuk menghasilkan formula yang paling optimal berdasarkan data respon dari parameter sediaan.

Tabel I3. Persamaan Simplex Lattice Design

\begin{tabular}{|c|c|}
\hline Respon & Persamaan \\
\hline Kekerasan Tablet & $Y=3, I(A)+4,2(B)-0,58(A)(B)$ \\
\hline Kerapuhan Tablet & $Y=0,04(A)+0, I I(B)+1,28(A)(B)$ \\
\hline Waktu Larut Tablet & $\mathrm{Y}=2,58(\mathrm{~A})+3,56(\mathrm{~B})+4,4 \mathrm{I}(\mathrm{A})(\mathrm{B})$ \\
\hline
\end{tabular}

Nilai $A$ adalah kadar proporsi asam sitrat dan nilai $B$ adalah kadar proporsi asam tartrat. Nilai positif pada masing-masing komponen menunjukkan efek yang sinergis, dimana jika komponen ditingkatkan maka nilai respon juga akan meningkat. Adapun nilai negatif menunjukkan efek yang berlawanan atau antagonis antara komponen dan respon. Besaran angka atau nilai menunjukkan besarnya pengaruh komponen terhadap respon yang dihasilkan (Fauzan H.A, 2019).

Berdasarkan hasil persamaan simplex lattice design yang diperoleh pada respon uji kekerasan tablet, menunjukkan efek yang negatif yaitu jika komponen asam sitrat dan asam tartrat ditingkatkan, maka akan terjadi penurunan nilai kekerasan tablet effervescent, artinya tablet akan semakin rapuh. Respon uji kerapuhan tablet memilliki efek positif, dimana jika komponen asam sitrat dan asam tartrat ditingkatkan maka nilai kerapuhan tablet juga akan semakin meningkat. Adapun pada respon uji waktu larut juga menunjukkan efek positif, dimana jika komponen asam sitrat dan asam tartrat ditingkatkan maka nilai respon dari waku larut tablet juga akan meningkat.

Formula optimal merupakan formula yang memiliki hasil respon berada pada rentang batas pada setiap parameter. Formula yang memiliki nilai desirability mendekati I merupakan formula yang paling optimal (Hidayat, I.R et al., 202I). Berdasarkan hasil software design expert metode simplex lattice design, didapatkan formula optimal asam sitrat yaitu 103,25 mg dan asam tartrat yaitu 44,24 mg dengan nilai desirability yaitu 0,999. Formula tersebut memiliki poin prediksi kekerasan tablet yaitu $3,10 \mathrm{~kg}$, kerapuhan tablet yaitu $0,04 \%$ dan waktu larut yaitu 2,58 menit.

\section{KESIMPULAN}

Kombinasi asam sitrat dan asam tartrat memiliki pengaruh terhadap evaluasi fisik kekerasan, kerapuhan dan waktu larut tablet effervescent ekstrak ubi jalar ungu. Konsentrasi asam sitrat dan asam tartrat paling optimal dari tablet effervescent ekstrak ubi jalar ungu berdasarkan metode simplex lattice design yaitu pada F5 dengan konsentrasi asam sitrat yaitu 103,25 mg dan asam tartrat yaitu $44,25 \mathrm{mg}$.

\section{UCAPAN TERIMA KASIH}


Peneliti mengucapkan terimakasih dan apresiasi sebesar-besarnya kepada Universitas Sari Mulia dan semua pihak yang terkait.

\section{REFERENSI}

I. Runtuwene, M.R., \& Wewengkang, D. (2016). Uji aktivits antioksidan dan toksisitas ekstrak etanol daun foki sabarati (Solanum torvum). Pharmacon, 5(3), 94- I0I.

2. Hamid, A.A., Aiyelaagbae, O.O., Usman, L.A., Ameen, O.M \& Lawal, A. (2010). Antioxidans : Its medicinal and pharmacological Applications, Vol. 4. no. 8, pp |42-I5I.

3. Forbes-Hernandez, T. Y., Gasparrini, M., Afrin, S., Cianciosi, D., Gonzales-Paramas, A.M., SantosBuelga, C., Mezzeti, B., Quiles, J.L., Battino, M.,Giamprieri, F., \& Bompadre, S. (2017). Strawberry (cv Romina) methanolic extract and anthocyanin-enriched fraction improve lipid profile and antioxidant status in HepG2 cells. International Journal of Melecular Science, 18 (6).

4. Wahyuningsih, S., Wulandari, L., Wartono, M.W., Munawaroh, H., \& Ramelan, A.H. (20I7). The effect of $\mathrm{Ph}$ and color stability of anthocyanin on food colorant. IOP Conference Series : Materials Science and Engineering, 193 (I).

5. Noval, N., Appriliani, R., \& Oktaviannoor, H. (202I). Evaluasi Pengaruh Konsentrasi Pati Biji Cempedak (Artocarpus champeden) sebagai Bahan Pengisi pada Formulasi Tablet Paracetamol. Jurnal Surya Medika (JSM), 6(2), I I II 18. https://doi.org/10.33084/jsm.v6i2.2127.

6. Priska, M., Peni, N., Carvallo, L., \& Ngapa, Y.D. (2018). Review : antosianin dan pemanfaatannya. Cakra Kimia (Indonesia E-Jurnal of Applied Chemistry). Volume 6 Nomor 2.

7. Safari, A et al. (2019). Ekstraksi dan penentuan antioksidan ekstrak ubi jalar ungu (Ipomoea batatas L.). al-Kimiya, Vol.6, no. 2. (46-5I).

8. Tristantini, D., Ismawati, A., Pradana, B. T., \& Gabriel, J. (2016). Pengujian Aktivitas Antioksidan Menggunakan Metode DPPH pada Daun Tanjung ( Mimusops elengi L ). Universitas Indonesia, 2.
9. Noval, N., Yuwindry, I., \& Syahrina, D. (2019). Phytochemical Screening and Antimicrobial Activity of Bundung Plants Extract by Dilution Method. Jurnal Surya Medika. https://doi.org//0.33084/jsm.v5il.954.

I0. Green, S.C., Noonan, P.K., Sanabria, C., \& Peacock, W. F. (20I6). Effervescent NAcetylcysteine Tablets versus Oral Solution NAcetylcysteine in Fasting Healthy Adults : An Open-Label, Randomized, Singel-Dose, Crossover, Relative Bioavailability Study. Current Therapeutic Research-Clinical and Experimental, 83, I-7.

II. Saifullah, M., Yusof, Y.A., Chin, N., Le., \& Aziz, M.G. (2016). Physicochemical and flow properties of fruit powder and their effect on the dissolution of fast dissolving fruit powder tablets. Powder Technology, 30I, 396-404.

12. Anova, I. T., Kamsina, K., \& Hermianti, W. (20I6). Formulasi perbandingan asam basa serbuk effervescent dari cokelat bubuk. Jurnal Litbang Industri. 6 (2), 99.

13. Anwar, K. (20I0). Formulasi sediaan tablet effervescent dari ekstrak kunyit (Curcuma domestica Val.) dengan variasi jumlah asam sitrat dan asam tartrat sebagai sumber asam. Sains dan Terapan Kimia. 4 (2), I68-I 78.

14. Ansel, H.C. (1989). Pengantar Bentuk Sediaan Farmasi (Terjemahan). Universitas Indonesia Press. Jakarta.

15. Mohrle, R., (1989). Effervescent Tablets, In Lieberman, H.A., Lachman, L., \% Schwartz, J.B. (editors), Pharmaceutical Dosage Forms Tablets, Vol. I, 2th Ed, Marcel Dekker Inc 225-255. New York.

16. Bolton, S. (1997). Pharmaecutical statistics : practical and clinical application, $3^{\text {rd }}$ ed, Marcel Dekker Inc. New York.

17. Aprilianto, A. (20II). Optimasi Kombinasi Aspartam- Tropicana Slim $®$ Sebagaipemanis Dalam Formulasi Tablet Effervescent Dari Ekstrak Kelopak Bunga Rosella (Hibiscus Sabdariffa L.) Dengan Metode Simplex Lattice Design. Khazanah, 4(I), I-8. https://doi.org/I0.20885/khazanah.vol4.iss I .art I . 
18. Ermawati, D. E., Sulaiman, S., \& Purwantini, I. (2017). Optimization Formula of Tumeric (Curcuma longa L.) Extract Chewable with Combination of Mannitol-Lactose as Filler Based on Simplex Lattice Design. JPSCR : Journal of Pharmaceutical Science and Clinical Research, 2(0I), 53.

19. Fauzan, HA., (2019). Optimasi Campuran Asam Sitrat dan Asam Tartrat pada Tablet Effervescent Ekstrak Buah Tin (Ficus carica L) dengan Metode Simplex Lattice Design. Universitas Islam Indonesia, Yogyakarta.

20. Septiani, S., Wathoni, N., \& Mita, S.R. (20II). Formulasi sediaan masker gel antioksidan dari ekstrak etanol biji belinjo. Fakultas Farmasi. Universitas Padjajaran, 2-4.

21. Mopuri, R., Ganjayi, M., Meriga, B., Koorbanally, N.A., \& Islam, M.S. (20I8). The effect of ficus carica on the activity of enzymes related to metabolic syndrome. Journal of Food and Drug Analysis, 26 (I), 20I-210.

22. Pradana, A.T., et al. (20I5). Formulasi floating tablet menggunakan variasi konsentrasi HPMC KIOOM terhadap kemampuan mengapung dan profil disolusi tablet ranitidine $\mathrm{HCl}$. Jurnal Ilmiah Sains dan Teknologi, 9(I) : II-2I.

23. Patel, H.K., Chauhan, P., Patel, K.N., Patel, B.A., \& Patel, P.A. (20I2). Formulation and evaluation of effervescent tablets of paracetamol and ibuprofen. International Journal for Pharmaceutical Research Scholars, I (2), 509-520.

24. Kemenkes RI. (20I4). Farmakope Indonesia Edisi V. Direktorat Jenderal Bina Kefarmasian dan Alat Kesehatan. Jakarta.

25. British Pharmacopoeia Volume IV. (2007). The Stationary Office on Behalf of Medicine and Healthcare Products Regulatory Agency (MHRA). England.

26. Noval, N., \& Rosyifa, R. (202I). Dispersi Padat untuk Peningkatan Laju Disolusi Natrium Diklofenak dengan Variasi Konsentrasi Polivinil Pirolidon K30. Jurnal Surya Medika (JSM), 6(2), 94I0I. https://doi.org/10.33084/jsm.v6i2.2125.
27. Anonim. (20|4). Farmakope Indonesia, Edisi V. Departemen Kesehatan Republik Indonesia. Jakarta.

28. Apriyanto, B.H., Rusli, R., Rahmadani, A. (2017). Evaluasi pati umbi talas (Colocasia esculenta Schott) sebagai bahan pengisi pada sediaan tablet Paracetamol. Proceeding of the $5^{\text {th }}$ Mulawarman Pharmaceuticals Conference. Fakultas Farmasi Universitas Mulawarman.

29. BPOM RI. (20|4). Peraturan Kepada Badan Pengawas Obat dan Makanan Republik Indonesia Nomor 12 Tahun 20/4 Tentang Persyaratan Mutu Obat Tradisional. BPOM RI.

30. Dewi, S. K. (20I0). Formulasi Sediaan Tablet Fast Disintegrating Antasida Dengan Starch 1500 Sebagai Bahan Penghancur Dan Laktosa Sebagai Bahan Pengisi. 23.

31. Noval, Noval, Melviani Melviani, Novia Novia, and Dahlia Syahrina. 2020. "Formulasi Dan Evaluasi Sediaan Obat Kumur (Mouthwash) Dari Ekstrak Etanol Tanaman Bundung (Actinoscirpus Grossus) Sebagai Antiseptik Mulut”. Jurnal Surya Medika $\begin{array}{llll}\text { (JSM) } & 6 & \text { (I), }\end{array}$ https://doi.org/10.33084/jsm.v6il.1626.

32. Anonim. (2016). The United States Pharmacopeia. 39-The National Formulary 34.

33. Alawiyah, R. (20/2). Formulasi tablet ekstrak etanol kulit buah rambutan (Nephelium lappaceum L.) dengan variasi kadar polivynilpyrolidone dan uji aktivitas antioksidan dengan metode DPPH. Skripsi. Universitas Islam Indonesia. Yogyakarta.

34. Voight, R. (1994). Pelajaran Teknologi Farmasi, (Terjemahan), Gadjah Mada University Press, Yogyakarta.

35. Banker, G.S dan Anderson, N.R. (1994). Tablet in the Theory and Practice of Industrial Pharmacy, Ed III, Diterjemahkan Oleh Siti Suyatmi, UI Press. Jakarta.

36. Aslani, A., \& Daliri, A. (2016). Design, formulation and evaluation of its physiochemical properties of acetaminophen, ibuprofen and caffeine as 
effervescent tablet. Journal of Reports in Pharmaceutical Sciences, 5 (2), 122-134.

37. Elisabeth, $\mathrm{V}$ et al. (2018). Formulasi sediaan granul dengan bahan pengikat pati kulit pisang goroho (Musa acuminafe L.) dan pengaruhnya pada sifat fisik granul. Jurnal Ilmiah Farmasi-UNSRAT. Vol.7, no.4.

38. Wicjaksono, A.A. (2020). Formulasi dan evaluasi tablet ekstrak temu putih (Curcuma zedoaria (Berg.) Roscoe) Sebagai antibakteri. Skripsi. Universitas Sari Mulia. Banjarmasin.

39. Lynatra, C., Wardiyah., Elisya, Y. (2018). Formulation of effervescent tablet of temulawak extract (Curcuma xanthorrhiza Roxb.) with variation of stevia as sweetener. Jurnal Teknologi dan Seni Kesehatan. Vol. 9, no. 2. 72-82.

40. Gusmayadi, I et al. (2018). Optimasi konsentrasi asam sitrat sebagai sumber asam terhadap waktu larut tablet effervescent ekstrak kering kulit buah manggis (Garcinia mangostana L). Jurnal IImiah IImu Kefarmasian. Vol.5, no. I.

4I. Khaidir, S et al. (20I5). Formulasi tablet ekstrak kangkung air (Ipomoea aquatica F.) dengan variasi kadar amilum manihot sebagai bahan penghancur. Jurnal Ilmiah Farmasi. Vol. I I, no.I.

42. Rori, W. M., et al. (20/6). Formulasi dan evaluasi sediaan tablet ekstrak daun gedi hijau (Abelmoschus manihot) dengan metode granulasi basah. Jurnal Ilmiah Farmasi. 5 (2): 243-250.

43. Murtini, G., Yetri E. (20/8). Bahan Ajar Farmasi Teknologi Solid. Kementrian Kesehatan Republik Indonesia. Jakarta.

44. Bejugam, $\mathrm{N}$ et al. (20/5). Tablet formulation of an active pharmaceutical ingredient with a sticking and filming problem:direct compression and dry granulation evaluation. Drug Development Industrial Pharmacy, 4I, 333-34I.

45. Kartikasari, D.S et al. (20I5). Formulasi tablet effervescent ekstrak rimpang jahe emprit (Zingiber officinale Rosc.) dengan variasi kadar asam sitrat dan asam tartrat. Tradisional Medicine Journal, 20 (2).
46. Noval, N., Nugraha, D. F., Nastiti, K., Syahrina, D., \& Novia, N. (202I). Local Natural Product Development in the Era of Covid 19 Pandemic. Indonesia Berdaya, 2(2), I33-I40.

47. Noval, N., Nastiti, K., Nugraha, D. F., Rahmadani, R., \& Alawiyah, T. (2020). PRODUK INOVASI HAND SANITIZER DARI AKAR BAJAKAH SEBAGAI UPAYA PENCEGAHAN DI MASA PANDEMI COVID-19. LOGISTA-Jurnal IImiah Pengabdian Kepada Masyarakat, 4(2), 305-3I 2.

48. Hakim A.R. (2019). Formulasi Tablet Efervescen dari Ekstrak Daun Tin (Ficus carica L.) Dengan Kombinasi Asam Sitrat-Asam Tartrat dan Natrium Karbonat. Universitas Islam Indonesia. Yogyakarta.

49. Ainurofiq, A., Azizah, N. (2016). Perbandingan penggunaan bahan penghancur secara intragranular, ekstragranular dan kombinasinya. Journal of Pharmaceutical Science and Clinical Research. OI (OI). Pp I-9.

50. Apsari, P.A et al. (20|8). Formulasi tablet effervescent ekstrak biji melinjo (Gnetum gnemon L.) menggunakan PEG 6000 sebagai lubrikan dan asam sitrat-asam tartrat sebagai sumber asam. Jurnal IImu-IImu MIPA. Vol. 18.

5I. Putri, Y.K \& Husni, P. (20I8). Artikel tinjaun : pengaruh bahan pengikat terhadap sifat fisik tablet. Farmaka. Vol. 16, no.I.

52. Syamsia., Pratiwi, R.D., \& Susana. (20/7). Sifat Fisik Tablet Dihiydroartemisinin-Piperaquin (DHP) Sediaan Generik dan Sediaan dengan Nama Dagang yang Beredar di KotaMadya Jayapura. Jurnal Ilmiah Farmasi-UNSRAT, Vol.6 no.3.

53. Yulianti, D.A \& Sutoyo, S. (202I). Formulasi tablet effervescent ekstrak daun katuk (Saorupus androgynus L. Merr) dengan variasi konsentrasi asam dan basa. Jurnal Farmasi Sains dan Terapan. Vol.8, no.l.

54. Syukri, $Y$ et al. (2018). Characterization formulation dan evaluation of glibenclamide with B-cyclodextrin inclution complexec tablets. Jurnal Kedokteran dan Kesehatan Indonesia. Vol.9, no. 3.

55. Kumala Sari, L.O.R et al. (2018). Optimasi formula tablet effervescent dispersi padat meloksikam 
menggunakan desain faktorial. E- Jurnal Pustaka Kesehatan. Vol.6, no.2.

56. Hidayat, I.R., Zuhrotun, A., \& Sopyan I. (202I). Design expert software sebagai alat optimasi formulasi sediaan farmasi. Majalah Farmasetika, 6 (I), 99-I 20.

57. D. Kurniawati, N. Noval, and K. Nastiti, "POTENSI ANTISEPTIK POLIHERBAL DAUN SIRIH (Piper betle), KULIT JERUK NIPIS (Citrus aurantifolia) DAN TANAMAN BUNDUNG (Actinuscirpus grossus) PADA TINDAKAN KEPERAWATAN DAN KEBIDANAN," Din. Kesehat. J. Kebidanan Dan Keperawatan, vol. II, no. I, PP. 420-43I, 2020, doi: I0.33859/dksm.vI lil.552.

58. Haryono, I. A., Noval, N., \& Nugraha, B. (202I). Formulasi Buah Tampoi (Baccaurea macrocarpa) dalam Sediaan Masker Gel sebagai Antiaging. Jurnal Surya Medika (JSM), 6(2), 102-II0. https://doi.org/10.33084/jsm.v6i2.2126.

59. Noval, N., \& Raihana, R. (2019). Efek Ekstrak Etanol Akar Pasak Bumi (Eurycoma Longifolia, Jack) terhadap Ekspresi HRAS pada Organ Hati Tikus Galur Sprague Dawley pada Pemberian Doxorubicin. Jurnal Surya Medika (JSM), 5(I), I I5130. https://doi.org//0.33084/jsm.v5il.952

60. Noorjannah, N., \& Noval, N. (2020). Uji Disolusi Terbanding Antara Sediaan Tablet Ramipril Generik Dan Bermerek. Journal of Pharmaceutical Care and Sciences, I (I), 45-54. 